ISTIGHNA, Vol. 2, No 1, Januari 2019 P-ISSN 1979-2824

Homepage: http://e-journal.stit-islamic-village.ac.id/index.php/istighna

Maskur Rosyid

Membincang Kembali Hubungan Syariah dan Filsafat

\title{
MEMBINCANG KEMBALI HUBUNGAN SYARIAH DAN FILSAFAT
}

\author{
Maskur Rosyid \\ (masykurxrejo@gmail.com) \\ Dosen Sekolah Tinggi Ekonomi Syariah (STES) Islamic Village Tangerang
}

\begin{abstract}
Abstrak: Mempertentangan Filsafat dengan Agama (Syariah) sama dengan mempertentangkan akal dengan wahyu sebagai sumber kebenaran. Diskursus tersebut memuncak ketika al-Ghazālī memberikan kritik tajam atas filsafat. Kritik tersebut dikritik oleh Ibn Rushd. Lebih dari itu, upaya rekonsiliasi filsafat dan Syariah diberikan oleh Ibn Rushd. Epistemologinya dibangun atas tiga hal, metode al-Khatabiyah (Retorika), metode al-Jadaliyyah (dialektika), dan metode al-Burhāniyyah (demonstratif) yang dilakukan dengan metode takwil. Dalam Bahasa ușūl al-fiqh, Ibn Rushd menggunakan metode al-jam' wa al-tawfíq. Akal dan wahyu diposisikannya secara proporsional. Akal dan wahyu sama-sama digunakan sebagai alat untuk menemukan pengetahuan tanpa mengunggulkan yang satu di atas yang lainnya.
\end{abstract}

Kata Kunci: Filsafat, Syariah, Takwil, Akal, Wahyu.

\section{A. Pendahuluan}

Diskursus filsafat dan syariah (agama) merupakan term yang rentan terhadap perselisihan dan pertentangan, sekaligus dapat dikategorikan sebagai bahan kajian yang syarat problema. Hal ini terbukti selama beratus tahun lamanya hingga sekarang masih selalu menyisakan ruang kosong untuk diperdebatkan. Berbeda dengan bidang kajian lainnya yang telah menemukan "pembakuan" wilayah kajian, seiring berkembangnya waktu seperti dalam lapangan kajian yang bersifat parsial seperti kajian tentang hukum, akidah (kepercayaan), dan lain sebagainya. Hal ini bisa jadi sebagai akibat dari sejarah yang secara tidak disadari telah merusak keharmonisan kedua bidang tersebut. ${ }^{187}$ Artinya, kedua term tersebut dalam sejarahnya telah dibedakan ke dalam dua kajian berbeda, bukan dalam satu kesatuan yang utuh. Akibat nyata dari pengkotakan kedua kajian tersebut adalah terjadinya persengketaan antara filsuf dan agamawan di satu sisi dan di sisi lain antara agamawan dan ilmuwan. Masing-masing pihak mengklaim

187 Muhammad Sholikhin, Filsafat dan Metafisika dalam Islam; sebuah Penjelajahan Nalar, Pengalaman Mistik, dan Perjalanan Aliran Manunggaling Kawula Gusti (Yogyakarta: Narasi, 2008), 53-54.

Peer reviewed under reponsibility of STIT ISLAMIC VILLAGE.

(C) 2018 STIT ISLAMIC VILLAGE, All right reserved, This is an open access article under 114 the CC BY SA license (https://creativecommons.org/licenses/by-sa/4.0/) 
ISTIGHNA, Vol. 2, No 1, Januari 2019 P-ISSN 1979-2824

Homepage: http://e-journal.stit-islamic-village.ac.id/index.php/istighna

Maskur Rosyid

Membincang Kembali Hubungan Syariah dan Filsafat

bahwa pihak merekalah yang merupakan produk sejarah Islam, sedangkan yang lainnya hanya merupakan anak atau bahkan penyimpangan dari sejarah yang ada.

Terlepas dari polemik yang terjadi, keduanya telah mewarnai dinamika ilmu pengetahuan dalam khazanah Islam. Bagi setiap orang yang akan mendalami pemahaman keagamaan "diwajibkan" bersentuhan dengan kedua kajian tersebut, yaitu filsafat dan agama (syariah). Keduanya secara terpisah telah memberikan implikasi yang signifikan terhadap paradigm berpikir seseorang. Hanya saja memang yang terjadi bahwa masih ada penolakan antara yang satu dengan yang lainnya dalam hal memberikan support. Misalnya dari golongan juris muslim ( $f u q a h \bar{a}^{\prime}$ ) dinilai lebih islamik dari pada golongan filsuf, dengan argument bahwa fuqaha telah menyandarkan pemikirannya pada wahyu, sementara filsuf berpusat pada akal semata. ${ }^{188}$ Hal ini berakibat pada justifikasi atas segala tindakan, bahwa yang wahyu kebenarannya bersifat pasti sedangkan yang 'aqlī bersifat relative. Akibat perbedaan dan pertentangan keduanya menjadikan filsafat sebagai ilmu yang tidak dapat dijadikan sebagai acuan kebenaran.

Sholikhin dalam hal ini menyatakan bahwa tajamnya pertentangan antara filsafat dan syariah (agama) ditengarai oleh satu sebab utama yaitu adanya implikasi masuknya literature mistis dalam Islam yang mencela filsafat. Hal ini

${ }^{188}$ Hal ini seolah-olah menjadi maklum adanya, sebab memang syariah dalam arti fikih lebih mendasarkan penalarannya pada arah deduksi makna wahyu. Namun demikian dalam sejarahnya justru fuqaha pertama sekaligus guru dari para fuqaha yaitu Abū Hanīfah lebih banyak menggunakan rasio dari pada merujuk pada nash yang ada, sehingga dikenal sebagai ahl al-ra'y. Berbeda dengan para penerusnya seperti Mālik dan al-Shāfi'‘̄ yang lebih dikenal sebagai ahl alhadīth. Tentang hal tersebut baca; Abū Hamīd al-Ghazālī, al-Mustashfā min 'Ilm al-Ușūl (Beirut: Dār al-Fikr, 1986). Ḥusayn Ḥamīd Ḥassan, Ușūl al-Fiqh (Mesir: t.p, 1970), M. Khalid Mas’ud, Islamic Legal Philosophy (Islamabad: Islamic Research Institute, 1984), Manna’ Khalīl Qațāan, alTashri' wa al-Fiqh al-Islāmī (Beirut: Dār al-Fikr, 1982), Fakhr al-Dīn al-Rāzī, al-Maḥṣū fì 'Ilm al-Ușūl al-Fiqh (Riyadh: Dār al-Fikr, 1981), Joseph Schact, An ntroduction to Islamic Law (Oxford: Oxford University, 1964). Muhammad Abū Zahra, Ușūl al-Fiqh (Mesir: Dār al-Fikr al'Arabī, t.th). 'Abd al-Wahha>b Khalla>f, 'Ilm $U s\} u>l$ al-Fiqh (Kairo: Dār al-Qalam, 1978). Sedangkan jelas bahwa pada dasarnya filsafat merupakan usaha untuk menemukan berbagai manifestasi melalui kerangka berpikir yang sistematis, teratur, dan radikal. Sehingga dalam hal ini berfilsafat seolah diartikan sebagai berpikir keluar dari teks keagamaan yang ada. Mungkin inilah salah satu sebab disusunnya Tahāfut al-Falāsifah karya al-Ghazālī yang menentang keras berfilsafat. Namun begitu, sepertinya al-Ghazālī telah terkurung dalam kerancuan tersebut sehingga secara tidak sadar ia telah mengkritik filsafat dengan cara kerja filsafat. Dalam hal itu kemudian muncul Tahāfut al-Tahāfut karya Ibn Rushd, yaitu sebuah karya yang menceritakan tentang kerancuan di dalam kerancuan. Lebih lanjut baca; Fuad Hasan, Pengantar Filsafat Barat (Jakarta: Pustaka Jaya, 1996). Jaih Mubarak, "Pengantar" dalam Cecep Sumarna, Rekonstruksi Ilmu (Bandung: Benang Merah Press, 2005). 
ISTIGHNA, Vol. 2, No 1, Januari 2019 P-ISSN 1979-2824

Homepage: http://e-journal.stit-islamic-village.ac.id/index.php/istighna

Maskur Rosyid

Membincang Kembali Hubungan Syariah dan Filsafat

khususnya terjadi pada rentang waktu antara abad VI sampai dengan abad VIII H (abad XIII sampai abad XV M). Di samping itu adanya anggapan umum bahwa pencarian jalan agama mengharuskan pencelaan terhadap filsafat atau dalam paham umum keagamaan murni menuntut pencelaan atas intelek dan penolakan terhadap pemahaman intelektual turut mempertajam hubungan syariah dan filsafat. ${ }^{189}$ Hal tersebut pada dasarnya adalah asumsi yang terlampau sederhana, sebab jika ditelaah lebih lanjut maka akan ditemukan hubungan yang sinergis antara keduanya baik dalam paham keagamaan maupun dalam mazhab hukum yang ada.

Hal ini tidak saja pernah terjadi dalam diskursus filsafat dan syariah, namun juga pernah terjadi antara tasawuf dan syariah. Banyak tulisan yang mencoba menghubungkan kedua term tersebut membuktikan adanya pertentangan yang sengit di antara keduanya. Umumnya pertentangan yang terjadi disebabkan perbedaan dalam hal pengambilan dalil. Jika yang dimaksudkan adalah menggabungkan keduanya dalam hal dalil yang berbeda maka tentu mustahil dilakukan. Akan tetapi apabila yang dimaksud penggabungan dalam status dalil yang sama maka akan sangat mungkin dilakukan.

Penggabungan antara filsafat dan syariah (agama, hukum) bukan tidak mungkin dilakukan. Hal ini dapat dilihat dari konsep paling fundamental dalam syariah yang dikenal dengan istilah maqāșid al-sharī'ah atau asrār al-sharī'ah atau panca jiwa syariah. ${ }^{190}$ Maqāṣid yang dimaksud adalah menjaga kemurnian agama, menjaga jiwa (nyawa manusia), menjaga akal, menjaga keturunan, dan

\footnotetext{
${ }^{189}$ Muhammad Sholikhin, Filsafat dan Metafisika dalam Islam, 55-56.

190 Konsep tersebut dapat ditelusuri dalam berbagai karya, baik klasik maupun kontemporer. Maqāșid al-sharī'ah pada dasarnya merupakan hasil dari pada kajian filsafat hukum Islam. Hal ini sebab dalam penemuan hikmah atau nilai filsufis di balik sebuah teks harus berani keluar dari teks itu sendiri dan lebih melihat kepada konteks yang ada. Pembahasan mengenai ruh syariat tersebut baca; Mușțafā Zayd, al-Mașlaḥah fi al-Tashrī’ al-Islāmī wa Najm al-Dīn al-Tüfì (ttp: Dār al-Fikr al-'Arābī, 1954). Ḥusayn Hamīd Hasan, Naẓariyah al-Maṣlaḥah (Kairo: Dār alNaḥụah al-'Arābiyah, 1971). 'Abd al-Wahhāb Khallāf, Maṣādir al-Tashrī' al-Islāmī fì mā lā Nașs fì hà (Kairo: Ma'had al-Dirāsāt al-‘Arabiyyah al-'Āliyah, 1955). Abū Isḥāq Ibrāhīm ibn Mūsā alLakhmi Al-Shāțibī, Al-Muwāfaqāt fì Ușūl al-Aḥkām, I (Kairo: Dār al-Fikr, $1341 \mathrm{H}$ ). Al-Ghazālī, al-Mustashfā min 'Ilm al-Ușūl, I (Bagdad: Musanna, 1970). Masdar F. Mas'udi, Meletakkan Kembali Maṣlahah Sebagai Acuan Syari'ah, dalam Jurnal 'Ulum al-Qur'an, Vol. VI, No. 3, 1995. Maskur Rosyid, Implementasi Konsep Maslahat al-Tufi (Magelang: PKBM "Ngudi Ilmu”, 2013).
} 
ISTIGHNA, Vol. 2, No 1, Januari 2019 P-ISSN 1979-2824

Homepage: http://e-journal.stit-islamic-village.ac.id/index.php/istighna

Maskur Rosyid

Membincang Kembali Hubungan Syariah dan Filsafat

menjaga harta (property). ${ }^{191}$ Kelimanya merupakan tujuan utama syariah, sehingga al-Ghazalī menyatakan bahwa menghilangkan salah satu saja dari kelima tujuan tersebut sama saja dengan menghancurkan agama. ${ }^{192}$ Tujuan-tujuan tersebut disepakati oleh seluruh juris muslim. Lebih dari itu Masdar. F Mas'udi menyatakan bahwa di mana ada masalahat maka di sana ada hukum Allah. ${ }^{193}$ Kelima tujuan tersebut jika ditelaah lebih lanjut maka akan ditemukan persamaan dengan teori keadilan dalam filsafat hukum.

Filsafat Islam pada dasarnya bertujuan untuk mempertemukan antara agama dengan filsafat. ${ }^{194}$ Permasalahan yang kemudian timbul adalah bagaimana mempertemukan agama sebagai wahyu Tuhan dengan filsafat sebagai hasil ciptaan dan pikiran manusia. Permasalahan ini muncul ketika kebenaran agama harus dipertemukan dengan kebenaran filsafat yang berlandaskan pemikiran dan logika manusia. Alternatif jawaban atas pertanyaan tersebut tidak lebih dari tiga kemungkinan. Pertama, berpegang teguh kepada agama dan menolak filsafat. Ini adalah pendapat orang beragama yang tidak berfilsafat. Kedua, sebaliknya, berpegang teguh kepada filsafat dan menolak agama, dan ini adalah pendapat orang yang berfilsafat dengan tidak mengindahkan kaidah-kaidah agama. Ketiga, mengupayakan pemaduan antara filsafat dengan agama menurut cara tertentu, dan cara inilah yang ditempuh oleh para filsuf muslim ataupun para filsuf yang memerhatikan kaidah-kaidah agama. ${ }^{195}$

Wacana tentang pemaduan antara agama dan filsafat termasuk salah satu obyek kajian yang menjadi tuntutan lingkungan Islam terutama menurut para

${ }^{191}$ Al-Ghazālī, al-Mustashfā, I, 287. Said Aqiel Siradj, Islam Kebangsaan Fiqh Demokratik Kaum Santri, (Jakarta: Pustaka Ciganjur, 1999), 4.

${ }^{192}$ Al-Ghazālī, al-Mustashfā, I, 287.

${ }^{193}$ Masdar F. Mas’udi, Meletakkan Kembali Maṣlaḥah Sebagai Acuan Syari'ah, 97.

${ }^{194}$ Hal ini didasarkan pada pembacaan atas konsep Maqāṣid al-sharī‘ah atau bisa disebut sebagai filsafat hukum Islam. Dalam filsafat tersebut jelas mengindikasikan bahwa filsafat berkolaborasi dengan wahyu yang terbatas tersebut untuk kemudian dijadikan sebagai asas dalam beragama. Juga didasarkan pada realitas para filsuf Muslim yang tentu ingin mendamaikan aspekaspek dalam keberagamaan yang justru merusak citra agama tersebut.

${ }^{195}$ Muhammad Yūsuf Mūsā, Bayn al-Dīn wa al-Falsafah: fì Ra y Ibn Rushd wa Falāsifah al- 'Aṣr al-Wasịț, (Kairo: Dār al-Ma'ārif, 1968), 45-46 lihat juga; Edy Chandra, "Relasi Agama dan Filsafat" artikel

dalam http://www.academia.edu/1887409/Relasi_Agama_dan_Filsafat_Menurut_Ibnu_Rushd diakses pada 23 September 2013, 00:46 WIB. 
ISTIGHNA, Vol. 2, No 1, Januari 2019 P-ISSN 1979-2824

Homepage: http://e-journal.stit-islamic-village.ac.id/index.php/istighna

Maskur Rosyid

Membincang Kembali Hubungan Syariah dan Filsafat

filsuf. Para filsuf Islam sebenarnya mempercayai bahwa agama adalah suatu kebenaran yang tidak dapat diragukan. Dan mereka menghormati nilai-nilai serta prinsip-prinsipnya. Namun mereka juga percaya akan keluhuran dan orisinalitas filsafat. Mereka melihat filsafat sebagai kebenaran yang tak diragukan, dan oleh karenanya, mereka tidak ingin mengorbankan filsafat karena agama dan tidak ingin membunuh agama demi filsafat. Untuk itu, tidak ada jalan lain kecuali berupaya memadukan agama dan filsafat serta menyingkirkan hal yang nampak bertentangan (paradoks) di antara keduanya. Ini berarti bahwa ide sinkretisme secara esensial adalah suatu keharusan bagi mereka, selama mereka berpegang teguh pada filsafat dengan tanpa mengurangi keteguhan mereka dalam memegang Islam serta meletakkan filsafat pada posisi yang sejajar dengan Islam.

Dalam sejarah perjalanannya, pemikiran filsafat di dunia Islam mengalami pertentangan dan perdebatan yang barangkali tidak dijumpai dalam sejarah tradisi pemikiran filsafat di manapun. Hal ini dapat dibuktikan dengan pernyataan bahwa di satu sisi keberadaan filsafat amat diagung-agungkan dan dianggap sebagai pelengkap kebenaran yang dibawa oleh agama, sementara di sisi lain, terutama kelompok yang diwakili oleh jumhur fuqaha- mereka secara umum antipati dengan perbincangan dan obyek pemikiran filsafat yang dalam pandangan mereka bisa menjerumuskan seseorang kepada kekafiran. ${ }^{196}$

Sehingga bisa dikatakan pemikiran filsafat dalam tradisi ahli hukum Islam tidak tampak secara umum digemari. Demikianlah selama beberapa ratus tahun umat Islam ada dalam suasana polemis yang berkepanjangan. ${ }^{197}$ Puncak dari penolakan terhadap tradisi keilmuan filsafat, adalah ditandai dengan diterbitkannya sebuah kitab yang berjudul Tahāfut al-Falāsifah, buah karya Hujjatul Islam Imam al-Ghazalī. Dasar-dasar pemikiran filsafat mulai diragukan kebenarannya, orang mulai diajak untuk menyangsikan atau ragu-ragu di dalam mencari kebenaran lewat filsafat dengan cara memperbandingkannya secara diametral dengan konsep-konsep keagamaan yang terdapat dalam Alquran dan Hadis.

\footnotetext{
${ }^{196}$ Lihat dalam; al-Ghazālī, Tahāfut al-Falāsifah (Kairo: Dar al-Ma’arif, 1928).

${ }^{197}$ Muhammed 'Abid al-Jabiri, Kritik Pemikiran Islam Wacana Baru Filsafat Islam, 69-dst.
} 
ISTIGHNA, Vol. 2, No 1, Januari 2019 P-ISSN 1979-2824

Homepage: http://e-journal.stit-islamic-village.ac.id/index.php/istighna

Maskur Rosyid

Membincang Kembali Hubungan Syariah dan Filsafat

Seolah-olah terdapat jurang yang dalam yang mampu memisahkan alur pemikiran filsafat yang spekulatif dengan konsep-konsep keagamaan yang mentradisi di kalangan umat Islam sebelumnya. Untunglah di kemudian hari tampil ulama, ahli fikih, sekaligus filsuf yang berusaha mengkoreksi dan mengkritisi kesalahan yang dibuat oleh Imam al-Ghazalī (dan ulama-ulama yang mengikutinya) sekaligus membersihkan segala tuduhan dan kesangsian yang dituduhkan terhadap pemikiran filsafat seperti selama ini. Ia adalah Muhammad Ibn Rushd, seorang ulama besar yang amat berjasa dalam mengembalikan kepercayaan sebagian ilmuwan kepada filsafat dan berusaha mendamaikan kembali pertengkaran yang terjadi antara fuqaha di satu sisi dengan filsuf di sisi yang lain. ${ }^{198}$ Dengan berusaha memberikan tawaran metodologis yang rasional dan sebegitu jauh tidak keluar dari semangat nash Alquran dan sunnah Nabi, Ibn Rushd dipandang telah berhasil menghentikan laju kematian "ruh" filsafat di dunia Islam.

Ide pemaduan agama dan filsafat yang dilakukan Ibn Rushd ini bukan tidak berdasar, namun justru dipengaruhi oleh berbagai macam persoalan yang rancu atas hubungan keduanya. Di satu sisi terdapat sekelompok orang yang menjelaskan hikmah di balik segala sesuatu menurut kepentingan dan pemahaman mereka sendiri. Hal ini tentu akan menjadi keruwetan tersendiri yang berakhir pada pemisahan agama dan filsafat. Lebih dari itu, latar belakang sosiologis di mana ia tinggal tidak begitu respek terhadap filsafat, bahkan cenderung memusuhi. Selain juga terdapat banyak konflik yang terjadi antara aliran yang satu dengan aliran yang lain yang mengaku paling benar karena merasa paling benar dalam beragama turut memperburuk keadaan agama. Hal yang paling logis yang memengaruhi pola pikir Ibn Rushd adalah kegemarannya atau bisa dikatakan "kefanatikannya" terhadap aliran aristotelenianisme membuatnya berpikir bahwa Aristoteles dalam berbagai pendapatnya tidak bertentangan dengan ajaran

${ }^{198}$ Ibn Rushd dalam menyelami lubuk filsafat telah menghasilkan berbagai karya. Maestro dalam bidang filsafat adalah Faṣl al-Maqāl fì mā Bayn al-Hikmah wa al-Sharì'ah min al-Ittiṣāl yang dimaksudkan untuk menjawab andanya kesesuaian antara agama dan filsafat dan Tahāfut alTahāfut yang dimaksudkan untuk menanggapi al-Ghazali tentang tuduhannya terhadap filsafat. 
ISTIGHNA, Vol. 2, No 1, Januari 2019 P-ISSN 1979-2824

Homepage: http://e-journal.stit-islamic-village.ac.id/index.php/istighna

Maskur Rosyid

Membincang Kembali Hubungan Syariah dan Filsafat

Islam. ${ }^{199}$ Dengan asumsi awal yang demikian patut kiranya mengapa Ibn Rushd berusaha "mati-matian" membela filsafat yang digelutinya.

Hipotesa tersebut hanya merupakan identifikasi awal dari indikasi kemuculan pikiran Ibn Rushd, sehingga memerlukan penelaahan lebih lanjut. Oleh karenanya, untuk menyajikan ulasan yang utuh dan komprehensif mengenai awal ide tersebut muncul sampai pada kesimpulan hubungan agama dan filsafat dalam perspektif Ibn Rushd maka penelitian ini menjadi menarik. Pertanyaan pokok yang diajukan adalah sebagai berikut. Bagaimana pandangan Ibn Rushd tentang pemanduan syariah dan filsafat? Serta bagaimana Ibn Rushd memosisikan keduanya?

\section{B. Diskursus Agama (Syariah) dan Filsafat}

\section{Dasar-dasar Metafisika dalam Islam}

Guna menghindari kekaburan makna, definisi perlu diuraikan. Metafisika berasal dari bahasa Yunani "meta" dan "physika" yaitu sesudah fisika. Istilah tersebut pertama kali muncul dalam empat belas buku Aristoteles yang diberi judul oleh Andronikos. Aristoteles sendiri tidak menggunakan istilah metafisika dan fisika, melainkan filsafat pertama dan filsafat kedua. Secara terminology, metafisika mempunyai beragam makna. Bisa bermakna upaya untuk mengarakterisasi eksistensi atau realitas sebagai sebuah kesatuan. Atau dapat juga dimaknai dengan usaha untuk menyelidiki alam yang berada di luar pengalaman atau untuk menyelidiki apa hakikat di balik realitas. Dengan demikian, dapat dipahami bahwa metafisika adalah suatu pembahasan falsafati yang komprehensif mengenai seluruh realitas atau segala sesuatu yang ada. ${ }^{200}$

Metafisika terbagi menjadi 2, ontology (metafisika umum) dan metafisika khusus (kosmologi, teologi, antropologi). Ontology diartikan dengan membahas segala sesuatu yang ada secara menyeluruh dan sekaligus. ${ }^{201}$ Ontology memiliki 3

199 'Abdul Maqsūd 'Abdul Ghan̄̄, Al-Tawfiq Bayn al-Dīn wa al-Falsafah 'Inda Falāsifah al-Islām fì al-Andalus (Agama dan Filsafat) terj. Saifullah \& Ahmad Faruq (Yogyakarta: Pustaka Pelajar, 2000), 5

200 Jan Hendrik Rapar, Pengantar Filsafat (Yogyakarta: Kanisius, 1996), 44.

${ }^{201}$ Jan Hendrik Rapar, Pengantar Filsafat, 45. 
ISTIGHNA, Vol. 2, No 1, Januari 2019 P-ISSN 1979-2824

Homepage: http://e-journal.stit-islamic-village.ac.id/index.php/istighna

Maskur Rosyid

Membincang Kembali Hubungan Syariah dan Filsafat

teori, idealism ${ }^{202}$, materialism ${ }^{203}$, dan dualism ${ }^{204}$. Metafisika kosmologi ${ }^{205}$ sebagai bagian dari metafisika khusus pada dasarnya meerupakan diskusi tentang alam dan ketertiban yang paling fundamental dari seluruh realitas. ${ }^{206}$ Sementara teologi metafisik $^{207}$ membahas mengenai eksistensi Tuhan dengan melepas diskusi tersebut dari agama. ${ }^{208}$ Keberadaan Tuhan dalam metafisika jenis ini coba dirasionalkan, menjadi sebuah sitim filsafat yang dipecahkan lewat metode ilmiah. Banyak filsuf yang telah berupaya membuktikan bahwa Tuhan itu ada ${ }^{209}$, baik melalui argument ontologis ${ }^{210}$, kosmologis ${ }^{211}$, argument teleologis ${ }^{212}$, maupun argument moral ${ }^{213}$. Terakhir, filsafat Antropologi, yaitu khusus membahas mengenai apa manusia. ${ }^{214}$

Hal yang patut menjadi bahan kajian dalam kaitannya metafisika dalam Islam adalah tentang konsep Tuhan. Keberadaan Tuhan dalam Islam tentu berbeda dengan konsep awal mengenai metafisika itu sendiri. Di awal dijelaskan bahwa konsep teologi metafisik adalah membahas Tuhan namun sekaligus memisahkan

${ }^{202}$ Idealisme mengajarkan bahwa segala sesuatu yang ada di alam ini pada dasarnya berada di alam ide. Pokok dari yang nyata sebenarnya tidak nyata ada melainkan gambaran dari apa yang ada di dalam idea tau tidak nyata. Tokoh idealism adalah George Berkeley (1685-1753), Immanuel Kant (1724-1804), dan George Wilhelm Friedrich Hegel (1770-1831).

${ }^{203}$ Materialism merupakan kebalikan dari idealism, yaitu meyakini bahwa yang ada adalah yang tampak nyata ada, sehingga menolak hal yang tidak nyata. Tokoh dalam materialism Leukippo dan Demokritos (460-370 SM), Thomas Hobbes (1588-1679), dan Ludwig Andereas Feuerbach (1804-1872).

${ }^{204}$ Dualism memadukan antara idealism dan materialism. Substansi segala sesuatu adalah material dan mental, fisik dan moral.

${ }^{205}$ Kosmologi berasal dari bahasa Yunani kosmos dan logos, dunia dan ilmu, percakapan.

${ }^{206}$ Jan Hendrik Rapar, Pengantar Filsafat, 47.

207 Teologi metafisik dikenal pula dengan istilah theodicea yang hanya membahas dan membenarkan mengenai kepercayaan kepada Tuhan Yang Mahakuasa.

${ }^{208}$ Jan Hendrik Rapar, Pengantar Filsafat, 47.

${ }^{209}$ Para filsuf tersebut antara lain; Anselmus, Deskartes, Thomas Aquinas, dan Immanuel Kant.

${ }^{210}$ Melalui argument ini mereka mengakui eksistensi Tuhan dengan pola piker sebagai berikut. Bahwa setiap manusia pasti memiliki ide, sementara itu realitas lebih sempurna dari pada ide, dengan demikian Tuhan pasti ada dan keberadaanNya tersebut tentu lebih sempurna dari pad aide manusia tentang Tuhan.

${ }^{211}$ Pola pikir yang dibangun dalam argument ini adalah sebagai berikut. Segala sesuatu pasti ada sebab, termasuk keberadaan alam. Dengan demikian, sebab adanya alam adalah sesuatu di luar alam tersebut yaitu Tuhan.

${ }^{212}$ Paham ini menyatakan bahwa segala sesuatu pasti ada tujuannya, dan adanya alam ini pasti ada tujuannya, sementara itu, pemilik tujuan adalah Tuhan.

${ }^{213}$ Manusia adalah makhluk moral yaitu dapat membedakan baik buruk, benar salah, oleh karena itu, moral tersebut pasti berdasar dan bersumber. Dasar dan sumber tidak lain adalah Tuhan.

${ }^{214}$ Jan Hendrik Rapar, Pengantar Filsafat, 50. 
ISTIGHNA, Vol. 2, No 1, Januari 2019 P-ISSN 1979-2824

Homepage: http://e-journal.stit-islamic-village.ac.id/index.php/istighna

Maskur Rosyid

Membincang Kembali Hubungan Syariah dan Filsafat

pembahasan tersebut dari campur tangan agama. Sedangkan Islam adalah agama maka metafisika agama dalam hal ini diartikan sebagai penelusuran atas Tuhan dalam kapasitas manusia dalam sebuah agama, dalam hal ini Islam.

Dalil (bukti) tentang Tuhan secara umum dibagi menjadi 2, dalil naqlī (ayatayat qawliyah) dan dalil 'aqli (ayat-ayat kawniyah). Namun demikian, berpikir tentang filsafat, khususnya metafisika ${ }^{215}$-eksistensi Tuhan, qadimnya alam, Tuhan tidak mengetahui perincian alam, tidak adanya kebangkitan jasmani, dan sebagainya- menurut al-Ghazzālī berakibat pada kekafiran. Sebagai seorang yang beriman, adalah wajib memercayai hal-hal ghaib, termasuk Tuhan, malaikat, dan hal-hal yang tidak Nampak lainnya.

Pemeliharaan Tuhan atas manusia -dalam kajian usul fikih hal ini disebut dengan konsep maqāṣid al-sharī'ah ${ }^{216}$ - merupakan bukti nyata dari adanya Tuhan. Tidak mungkin Tuhan menciptakan makhluk -manusia- tanpa memerhatikan kebaikan untuk mereka. Hal itu tentu sangat mustahil, sebab Tuhan Maha atas

${ }^{215}$ Perincian persoalan yang menjadi perdebatan dalam sejarah filsafat metafisika Islam adalah sebagai berikut. Alam qadìm (tidal bermula), Keabadian ('abadiah) alam, masa dan gerak, Konsep Tuhan sebagai pencipta alam dan bahwa alam adalah produk ciptaan-Nya; uangkapan ini bersifat metaforis, Demonstrasi/ pembuktian eksistensi Penciptaan alam, Argumen rasional bahwa Tuhan itu satu dan tidak mungkin pengandaian dua wajib al wujud, Penolakan akan sifat-sifat Tuhan, Kemustahilan konsep genus (jins) kepada Tuhan, Wujud Tuhan adalah wujud yang sederhana, wujud murni, tanpa kuiditas atau esensi, Argumen rasional bahwa Tuhan bukan tubuh (jism), Argumen rasional tentang sebab dan Pencipta alam (hukum alam tak dapat berubah), Pengetahuan Tuhan tentang selain diri-Nya dan Tuhan mengetahui species dan secara universal, Pembuktian bahwa Tuhan mengetahui diri-Nya sendiri, Tuhan tidak mengetahui perincian segala sesuatu (juz'iyyat) melainkan secara umum, Langit adalah mahluk hidup dan mematuhi Tuhan dengan gerak putarnya, Tujuan yang menggerakkan, Jiwa-jiwa langit mengetahui partikularpartikular yang bermula, Kemustahilan perpisahan dari sebab alami peristiwa-peristiwa, Jiwa manusia adalah substansi spiritual yang ada dengan sendirinya, tidak menempati ruang, tidak ter pateri pada tubuh dan bukan tubuh, Jiwa manusia setelah terwujud tidak dapat hancur, dan watak keabadiannya membuatnya mustahil bagi kita membayangkan kehancurannya, dan Penolakan terhadap kebangkitan Jasmani.

${ }^{216}$ Maqāșid al-sharī'ah yang diartikan sebagai ruh dari segala peraturan Tuhan disebut juga sebagai filsafat hokum Islam (falsafah al-tashrī'). Konsep tersebut sebagai landasan berpikir bagi para pemangku kebijakan. Menafikannya sama dengan menghilangkan agama itu sendiri. Ibn 'Āshūr membagi maqāssid atau mașlaḥah ke dalam tiga pembagian; pertama dari sisi pengaruhnya terhadap tegaknya urusan umat, maka terbagi menjadi tiga; darūriyyah, häjiyyah, dan tahsiniyyah. Sedangkan dari segi hubungannya dengan umat, kelompok, atau individu, maka terbagi menjadi dua; kulliyyāt dan juz'iyyāt. Sementara jika dari sisi terwujudnya kebutuhan kepada maslahat dalam melaksanakan urusan umat, kelompok, atau individu, maka terbagi menjadi tiga; qat'iyyah, zanniyyah, dan wahmiyyah. Lihat Ibn 'Āshūr, Maqāṣid, 76. Baca juga, al-Shāțibī, al-Muwāfaqāt, 8-12. Ibn Qudamah, Rawḍah al-Nadhīr wa al-Ju'annah al-Munādhir (Beirut: Mu'asasah alRisālah, 1978), 414. Al-Ghazālī, al-Mustashfā, II: 139. 'Alī Ḥasaballāh, Uṣūl al-Tashrī' al-Islāmī (Qahirah: Dār al-Fikr al-'Arabī, 1997), 45. 
ISTIGHNA, Vol. 2, No 1, Januari 2019 P-ISSN 1979-2824

Homepage: http://e-journal.stit-islamic-village.ac.id/index.php/istighna

Maskur Rosyid

Membincang Kembali Hubungan Syariah dan Filsafat

segala yang ada di dunia ini, termasuk kebaikan bagi setiap manusia. Kemaslahatan (al-mașlaḥah) kendatipun bukan kewajiban yang di bebankan kepada Tuhan, melainkan kewajiban yang Tuhan bebas menentukan untuk diriNya bukan kewajiban yang berasal dari luar dirinya. ${ }^{217}$

Dalil Ikhtira' (dalil ciptaan) Dalil ini didasarkan pada fenomena ciptaan segala makhluk ini, seperti ciptaan pada kehidupan benda mati dan berbagai jenis hewan, tumbuh-tumbuhan dan sebagainya. Menurut Ibn Rushd, kita mengamati benda mati lalu terjadi kehidupan padanya, sehingga yakin adanya Allah yang menciptakannya. Demikian juga berbagai bintang dan falak di angkasa tundujk seluruhnya kepada ketentuannya. Karena itu siapa saja yang ingin mengetahui Allah dengan sebenarnya maka ia wajib mengetahui hakikat segala sesuatu di alam ini agar ia dapat mengetahui ciptaan hakiki pada semua realitas ini. Ayat suci yang mendukung dalil tersebut, di antaranya Q.S, al-Hajj: 73

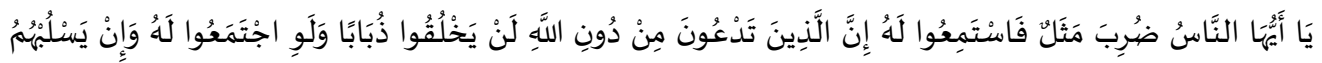

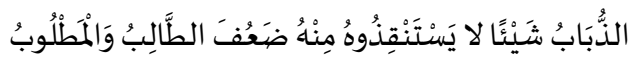

Artinya: "Hai manusia, telah dibuat perumpamaan, maka dengarkanlah olehmu perumpamaan itu. Sesungguhnya segala yang kamu seru selain Allah sekali-kali tidak dapat menciptakan seekor lalat pun, walaupun mereka bersatu untuk menciptakannya. Dan jika lalat itu merampas sesuatu dari mereka, tiadalah mereka dapat merebutnya kembali dari lalat itu. Amat lemahlah yang menyembah dan amat lemah (pulalah) yang disembah" (QS. Al-Hajj:73).

Dalil Harakah (Gerak). Dalil ini berasal dari Aristoteles dan Ibn Rushd memandangnya sebagi dalil yang meyakinkan tentang adanya Allah seperti yang digunakan oleh Aristoteles sebelumnya. Dalil ini menjelaskan bahwa gerak ini tidak tetap dalam suatu keadaan, tetapi selalu berubah-ubah. Dan semua jenis gerak berakhir pada gerak pada ruang, dan gerak pada ruang berakhir pada yang bergerak pad dzatnya dengan sebab penggerak pertama yang tidak bergerak sama

217 Perdebatan seputar kewajiban Tuhan memelihara kebaikan manusia melibatkan kelompok Mu'tazilah, Ash'ariyah, dan Maturidiyyah. Najm al-Dīn al-Ṭūề dalam hal ini mengambil jalan tengah sebagaimana disebutkan di atas. Baca; Muṣțafā Zayd, al-Maṣlaḥah fì alTashrī‘ al-Islāmī wa Najm al-Dīn al-Ṭ̂̄fì 214. 
ISTIGHNA, Vol. 2, No 1, Januari 2019 P-ISSN 1979-2824

Homepage: http://e-journal.stit-islamic-village.ac.id/index.php/istighna

Maskur Rosyid

Membincang Kembali Hubungan Syariah dan Filsafat

sekali, baik pada dzatnya maupun pada sifatnya. Akan tetapi, Ibn Rushd juga berakhir pada kesimpulan yang dikatakan oleh Aristoteles bahwa gerak itu qadim.

Sifat-sifat Allah. Adapun pemikiran Ibn Rushd tentang sifat-sifat Allah berpijak pada perbedaan alam gaib dan alam realita. Untuk mengenal sifat-sifat Allah, Ibn Rushd mengatakan, orang harus menggunakan dua cara, tasbịh dan tanzịh (penyamaan dan pengkudusan). Berpijak pada dasar keharusan pembedaan Allah dengan manusia, maka tidak logis memperbandingkan dua jenis ilmu itu.

\section{Syariah}

Al-Ashmawī mengatakan bahwa jika seseorang ditanya tentang makna syariah Islam maka orang tersebut pasti akan diam. ${ }^{218}$ Bisa jadi hal ini disebabkan karena yang dimaksud dengan istilah tersebut sudah jelas maksudnya yaitu Alquran dan hadis. Namun begitu pertanyaan kemudian melebar kepada Alquran itu sendiri, apa yang disebut sebagai syariat dalam Alquran? Ayat-ayat apa yang bisa digolongkan ke dalam golongan syariah? Ayat hukum atau ayat yang lainnya juga bisa disebut sebagai syariah? Bagaimana nasib ayat hukum misalnya (jika hanya ayat hukum yang disebut sebagai syariah) yang mansū $k h^{219}$ dan yang $n \bar{a} s i k h^{220}$ ? Belum lagi ketika dipertanyakan bagaimana ayat yang hanya ditujukan untuk Nabi? Atau untuk umat tertentu juga diberlakukan untuk umat yang lainnya? Dan sederet pertanyaan terkait syariah.

Syariah, jika ditelusuri lebih lanjut, merupakan bahasa Arab yang telah ada jauh sebelum Alquran turun. Hal serupa juga disebutkan dalam Taurat dan Injil. Taurat menyebutnya -dengan bahasa Ibrani- sebanyak 200 kali, yang semuanya bermakna "kehendak Tuhan yang diwahyukan sebagai wujud kekuasaan-Nya atas segala perbuatan manusia". ${ }^{221}$ Dengan demikian, syariah dalam Taurat tidak

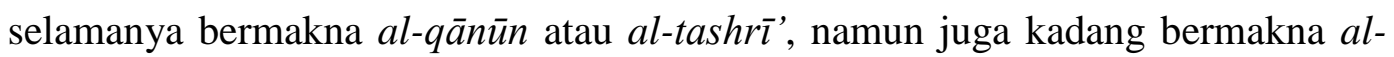

218 Muhammad Sa‘̄id al-Ashmawī, Nalar Kritis Syari’ah (Terj. Luthfi Tomafi) (Yogyakarta: LKiS, 2012), 2-3.

${ }^{219}$ Mansūkh adalah ayat-ayat Alquran yang dihapus, baik lafaz maupun segi kandungan ajarannya. Seperti hukuman potong tangan sebagai akibat pencurian dinasakh oleh hadis Nabi yang menyatakan bahwa hukuman potong diberlakukan jika pencurian melebihi 1/4 dinar, dan sebagainya.

${ }^{220} N \bar{a} s i k h$ adalah ayat atau hadis yang menghapus lafaz atau kandungan ajaran pada ayat sebelumnya.

${ }^{221}$ Lebih lanjut baca; Muhammad Sa‘̄id al-Ashmawī, Nalar Kritis Syari’ah, 8-16. 
ISTIGHNA, Vol. 2, No 1, Januari 2019 P-ISSN 1979-2824

Homepage: http://e-journal.stit-islamic-village.ac.id/index.php/istighna

Maskur Rosyid

Membincang Kembali Hubungan Syariah dan Filsafat

manhaj atau al-țarīqah. Sedangkan dalam Injil, syariah disebutkan dengan istilah $n \bar{a} m \bar{u} s$ yang berasal dari bahasa Yunani "kavmv" yang bermakna as $\bar{a} s$ atau pondasi yang lurus. Makna yang mendekati kebenaran adalah perbuatan untuk meluruskan sesuatu, yaitu syariah dalam pengertiannya yang umum yang berarti aturan orang-orang yang dekat dan merupakan ruh agama. ${ }^{222}$

Alquran menyebutkan kata syarī'ah sekali saja yaitu dalam Surah alJāthiyah (45): 18 sebagai berikut.

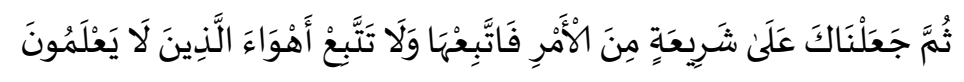

Artinya: "Kemudian Kami jadikan engkau (Muhammad) mengikuti syariat (peraturan) dari agama itu maka ikutilah (syariat itu) dan janganlah engkau ikuti keinginan orang-orang yang tidak me-ngetahui"

Selanjutnya disebutkan juga dalam bentuk kata kerja $\left(f i{ }^{\prime} i l\right)$ dan derivatnya sebanyak 3 kali sebagai berikut. Pertama; disebutkan dengan lafaz شَعَ dalam QS. Al-Shūrā (42): 13. ${ }^{223}$ Kedua; disebutkan dengan lafaz شِرِعَاً dalam QS. Al-Mā'idah (5): $48^{224}$, dan ketiga; disebutkan dalam QS. Al-Shūrā (42): 21 dengan lafaz .شَرَعُوُ 225 Syariah atau pecahan dari kata tersebut dalam beberapa literature dimaknai secara etimologi dengan warada (datang) dan tempat mengalirnya air. ${ }^{226}$

Makna atas kata al-sharī'ah maupun al-shir'ah adalah agama yang digariskan Tuhan dengan segala perintahnya, seperti salat, zakat, puasa, dan haji, serta seluruh amal perbuatan yang baik yang bukan merupakan bukum muamalah. Dengan demikian, kata syariah yang disebutkan di sini bukan bermakna legislasi hukum (al-tashrī') atau undang-undang (qānūn). Sebab, kata شرع dan الشريعة dalam Alquran tersebut merupakan ayat Makiyah, yang berarti bahwa ayat

${ }^{222}$ Muhammad Sa'īd al-Ashmawī, Nalar Kritis Syari'ah, 18-19.

${ }^{223}$ Ayat tersebut berbunyi;

${ }^{224}$ Ayat tersebut berbunyi;

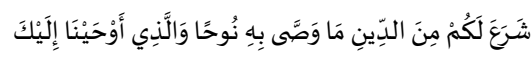

${ }^{225}$ Ayat tersebut berbunyi;

لِكُكِلِ جَعَلْنَا مِنْكُمْ شِرْعَاًَ وَمَنْهَاجًا

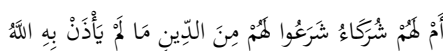

226 Lihat misalnya dalam A.W Munawwir, Kamus al-Munawwir Arab-Indonesia Terlengkap (Surabaya: Pustaka Progressif, 1997). Ibn Manzuūr, Lisān al- 'Arab. 
ISTIGHNA, Vol. 2, No 1, Januari 2019 P-ISSN 1979-2824

Homepage: http://e-journal.stit-islamic-village.ac.id/index.php/istighna

Maskur Rosyid

Membincang Kembali Hubungan Syariah dan Filsafat

tersebut turun sebelum legislasi yang turun dalam periode Madinah. Walaupun kata الشرعة turun sebagai ayat Madaniyah, namun juga bukan merupakan ayat hukum. $^{227}$

Syariah digunakan untuk menunjukkan arti agama (Islam) itu sendiri. Jika merujuk pada konsep yang Nabi berikan maka syariah memiliki 3 unsur penting yaitu iman, Islam, dan ihsan, serta segala ketentuan yang berkenaan dengan tingkah hidup manusia. ${ }^{228}$ Pada masa awal Islam, syariah dimaknai sama dengan al-fiqh. Namun kemudian makna dari keduanya menjadi berbeda pada masa selanjutnya.

\section{Diskursus tentang Syariah}

Syariah yang pada awalnya bermakna sama dengan baik dengan agama (dīn) maupun dengan fikih, kemudian menjadi berbeda ketika Abū Hanīfah dalam al-'Ālim wa al-Muta'allim menjelaskan tentang keduanya. Abū Hanīfah menjelaskan bahwa al-dīn selamanya tidak akan berubah. Hal ini sebagaimana keyakinan tentang agama para nabi yaitu agama tauhid. Hanya saja berbeda dalam aturan (syariah), sehingga syariah akan selalu mengalami perubahan. ${ }^{229}$

A.A Fyzee menjelaskan secara apik tentang definisi syariah yang berbeda dengan fikih. Ia menjelaskan bahwa syariah mempunyai ruang lingkup yang lebih luas, sementara fikih hanya berkecimpung mengenai aturan-aturan hukum (halalharam). Jika syariah hanya bisa diketahui dengan membaca sumber utamanya yaitu Alquran dan hadis maka fikih membutuhkan penalaran yang lebih. ${ }^{230}$

Lebih dari itu, Umar Sulaiman menjelaskan bahwa setidaknya ada 5 perbedaan antara syariah dan fikih. ${ }^{231}$ Pertama; syariah tidak berubah sementara fikih selalu berubah mengikuti perkembangan zaman dan tempat. Kedua; keduanya bisa jadi sama dalam hal ijtihad fiqhī yang benar, namun jika ternyata

${ }^{227}$ Muhammad Sa‘̄id al-Ashmawī, Nalar Kritis Syari’ah, 21.

${ }^{228}$ Konsep tersebut disebutkan dalam hadis Nabi saw. Ketika beliau berdialog dengan Malaikat Jibril a.s bahwa ajaran Islam itu terdiri atas iman, Islam, dan iḥsān. (H.R al-Bukhārī)

${ }^{229}$ Abū Ḥanīfah, al-'Ālim wa al-Muta'allim, 5-6 dalam Mun'im A. Sirri, Sejarah Fiqih Islam Sebuah Pengantar (Surabaya: Risalah Gusti, 1996), 16-17. 1964), 21.

${ }^{230}$ Asaf A.A Fyzee, Outlines of Muhammadan Law (Oxford: Oxford University Press,

${ }^{231}$ Umar Sulayman, Tārikh al-Fiqh al-Islām (Kuwait: Maktabah al-Falah, 1982), 21. 
ISTIGHNA, Vol. 2, No 1, Januari 2019 P-ISSN 1979-2824

Homepage: http://e-journal.stit-islamic-village.ac.id/index.php/istighna

Maskur Rosyid

Membincang Kembali Hubungan Syariah dan Filsafat

salah maka hasil ijtihad tersebut tidak dapat disebut sebagai syariah. Ketiga; syariat bersifat universal dan berlaku untuk seluruh umat, sementara fikih bisa jadi antara satu daerah dengan daerah yang lainnya berlainan. Keempat; aturan dalam syariah harus dilaksanakan dan larangannya harus ditinggalkan, sementara fikih bisa dilaksanakan bagi orang yang memahaminya, dan terakhir kelima; kebenaran syariah bersifat mutlak, sementara fikih bersifat nisbi.

Namun demikian pada masa dewasa ini, sering kali kata syariah dimaknai dengan fikih. Hal ini tentu mengandung arti penyempitan makna syariah. Syariah yang pada awalnya dimaknai sebagai agama (al-dīn) -meskipun Abū Ḥanīfah berbeda dalam menggunakan istilah ini, namun dapat dikombinasikan dengan $a l$ dīn = al-sharī'ah dan al-sharī'ah (dalam pandangan Abū Hanīfah) = fikihkemudian dimaknai sebatas hukum-hukum saja (fikih).

Oleh karenanya jika diskusi seputar syariah dalam arti fikih dibenturkan dengan ragam ilmu yang lain maka hal itu tentu sangat wajar. Sebab, tentu berbeda antara iman (akidah) dengan Islam (syariah atau fikih), berbeda pula antara Islam (syariah atau fikih) dengan ihsan (tasawuf), juga antara fikih dengan filsafat. Hal ini merupakan ragam kekayaan ilmu pengetahuan Islam sebagai sebuah agama. Hanya saja kemudian menjadi salah ketika masing-masing faham mengaku paling benar sehingga faham yang lain sesat. Hal ini pernah terjadi dalam sejarah Islam. ${ }^{232}$ Namun ketika memisahkan antara syariah (agama atau $a l$ $d \bar{\imath} n$ ) dengan tasawuf (mistisisme, ihsan) atau antara syariah (agama, al-dīn) dengan filsafat maka hal tersebut menjadi sangat menarik.

Diskusi selanjutnya diarahkan kepada perdebatan mengenai syariah dan tasawuf. Pada awalnya, tasawuf dengan syariah terintegrasi dengan baik

${ }^{232}$ Fanatisme mazhab berimplikasi terhadap pola pikir dalam hukum, tentu saja yang menguntungkan mazhab mereka. Sebagai contoh riil adalah tindakan pemalsuan hadis dan beberapa kodifikasi buku yang ditujukan untuk memuji pendapat imam mazhab mereka sekaligus mencaci pandangan imam mazhab yang lain. Sekat antar mazhab terpotret jelas ketika itu, masingmasing mazhab mempunyai wilayah jajahannya sendiri. Konon wilayah yang bukan merupakan wilayah mazhabnya dianggap sebagai wilayah perang. Catatan sejarah pernah menorehkan sejarah buruk ini, misalnya wilayah Jailan yang merupakan wilayah penganut mazhab Hanbalī tidak sungkan-sungkan melayangkan pedang kepada pendatang yang bukan dari mazhab Hanbalī sehingga harta yang dirampas dianggap sebagai harta fay'. Begitu pula Masjid yang dikhususkan bagi penganut mazhab tertentu dan tertutup untuk golongan lain. Mușțafā Zayd, al-Maṣlaḥah fì alTashrì' al-Islāmì wa Najm al-Dīn al-Ṭ̂̆fi, 228 dalam Maskur Rosyid, Implementasi Konsep Maṣlaḥat al-Ṭüfi dalam Fatwa MUI (2005-2010) (Magelang: PKBM “Ngudi Ilmu”, 2013), 30. 
ISTIGHNA, Vol. 2, No 1, Januari 2019 P-ISSN 1979-2824

Homepage: http://e-journal.stit-islamic-village.ac.id/index.php/istighna

Maskur Rosyid

Membincang Kembali Hubungan Syariah dan Filsafat

sebagaimana pola hidup Nabi saw. mengajarkannya. Nabi saw pernah menegur 'Abd Allāḥ bin 'Amr bin al-'Aṣ dan 'Usmān bin Madh'ūn yang melakukan ritual spiritual tanpa podasi syariah yang kokoh. ${ }^{233}$ Orientasi keagamaan eksoteris bertumpu pada legal formal hukum mengklaim sebagai paham keagamaan yang menempati posisi jalan kebenaran. Sementara itu, orientasi keagamaan esoteric yang bertumpu pada pengalaman dan kesadaran berujung pada jalan kebahagiaan.

Ibn Taymiyah dalam hal orientasi kedua ragam di atas (eksoteris dan esoteric) melukiskannya seperti pertentangan antara kaum Yahudi dan Nasrani ${ }^{234}$ yang disebutkan dalam Alquran Surah Al-Baqarah (2): 113. ${ }^{235}$ Pertentangan tersebut mencapai puncaknya pada sikap saling merasa benar, dan menyalahkan kelompok lain. Kelompok esoteric mengklaim bahwa mereka telah memerhatikan rūh al- 'amal dengan mendalami haqà 'iq al-ma'rifah yang mereka dapat langsung dari Tuhan, sementara kaum eksoteris dinilai hanya menghabiskan umur mereka untuk ilmu lahiriyah dan mengambil ilmu mati dari orang-orang mati. ${ }^{236}$

Upaya pemaduan 2 tema tersebut pertama kali dilakukan oleh Imām Mālik من تصوف ولم يتفقه فقد ibn Anas (w.179 H). Imām Mālik mengeluarkan statemen yang artinya siapa saja yang mengamalkan tasawuf tanpa mengetahuai atau tanpa landasan fikih maka orang tersebut telah zindiq (menyimpang). Pandangannya tersebut berusaha memadukan ilmu akal dan ilmu hati ( 'ilm al- 'aql wa 'ilm al-qalb). Lebih lanjut ia berkomentar bahwa ilmu bukan disandarkan pada

233 'Abd Allāḥ bin 'Amr bin al-'Aṣ dan 'Usmān bin Madh’ūn telah mencoba melakukan sebuah kehidupan spiritual dengan tujuan mencari rida Allah, dengan puasa sepanjang hari sehingga tidak berbuka dan malam hari untuk salat sehingga tidak tidur. Namun kemudian ditegur oleh Nabi saw., bahwa yang demikian itu merupakan tindakan yang tidak adil, sebab setiap yang Allah berikan mempunyai hak untuk diberikan keadilan. Lihat hadis dimaksud dalam; 'Abd alRaḥmān al-Jawzī al-Baghdādī, Talbīs al-Iblīs (Kairo: Idārah al-Ṭibā’ah al-Munīriyah, 1368 H), 219-220.

${ }^{234}$ Ibn Taymiyah, Iqtiḍ̄a' al-Șirāt al-Mustaqīm (Beirut: Dār al-Fikr, t.th), 10.

235 Ayat tersebut berbunyi;

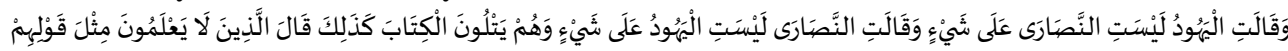

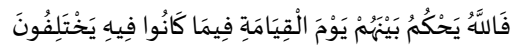

${ }^{236}$ Husayn Mu’nis, 'Ālam al-Islām (Kairo: Dār al-Ma'ārif, 1973), 227. Lihat juga, Asep Usman Ismail, "Integrasi Syariah dengan Tasawuf" dalam Ahkam Jurnal Ilmu Syariah, Vol. xii, No. 1, 2012, 134. 
ISTIGHNA, Vol. 2, No 1, Januari 2019 P-ISSN 1979-2824

Homepage: http://e-journal.stit-islamic-village.ac.id/index.php/istighna

Maskur Rosyid

Membincang Kembali Hubungan Syariah dan Filsafat

banyaknya referensi namun lebih kepada $n \bar{u} r$ atau cahaya yang disematkan oleh Tuhan di dalam hati. ${ }^{237}$

Dengan demikian, Imām Mālik berhasil meyakinkan atau mengintegrasikan kedua pembahasan tersebut dengan menekankan pentingnya mempelajari fikih (syariah) sebagai dasar pijakan keberagamaan setiap individu, serta tetap meyakini bahwa ilmu yang sebenarnya adalah $n \bar{u} r$ yang hanya Tuhan yang berhak memberikannya. Perjuangan menyatukan persepsi bahwa al-hikmah adalah al-figh tersebut diteruskan oleh tokoh-tokoh terkemuka lainnya seperti al-Qushayrī (w. $465 \mathrm{H}$ ), dan mengalami puncaknya di tangan al-Ghazālī. Ia berhasil memadukan corak ilmu lahiriyah dengan ilmu batiniyah tersebut yang kemudian dikenal dengan tasawuf sunni yaitu pengalaman tasawuf dengan bimbingan Alquran dan sunah Nabi saw. ${ }^{238}$

Syariah adalah hukum (law) sedangkan tasawuf adalah moral (morality). Syariah adalah hukum sedangkan tasawuf adalah akhlak, sehingga akhlak mendasari hukum dan hukum ditegakkan di atas landasan akhlak. Lebih lanjut N. J. Coulson mengatakan "the Islamic law is, in our terminology, both a code of law and a code of morals. It is a comprehensive scheme of human behavior which derives from the one ultimate authority of the will of Allāh; so that deviding line between law and morality is by no means so clearly drawn as it is in Western societies generally". 239

Demikian menjadi sebuah catatan, bahwa syariah pernah bersinggungan dengan segala aspek ragam ilmu pengetahuan lainnya. Hal ini menurut hemat penulis disebabkan oleh perbedaan paradigma dalam memahami syariah secara khusus dan dalam memahami Islam sebagai agama. Terlebih jika berkiblat pada aliran teologi yang juga pernah mewarnai sejarah Islam, seseorang yang dalam pikirannya mendasarkan pada akal tentu akan lebih condong kepada paradigm

\footnotetext{
${ }^{237}$ Ibn Khaldūn, "Shifā' al-Masā'il li Tahdhīb al-Masā'il”, dalam 'Abd al-Qādir Maḥmūd, al-Falsafah al-Șūfiyah fì al-Islām (Kairo: Dār al-Fikr al-'Arabī, 1966), 92.

${ }^{238}$ Abū Ḥāmid al-Ghazzālī, Fayṣāl al-Tafarruqah Bayn al-Islām wa Zindīqah (Beirut: alMaktab al-Islāmī, 1390 H), 6

${ }^{239}$ Noel J. Coulson, Conflicts and Tensions in Islamic Jurisprudence (Chicago \& London: the University of Chicago Press, 1969), 79.
} 
ISTIGHNA, Vol. 2, No 1, Januari 2019 P-ISSN 1979-2824

Homepage: http://e-journal.stit-islamic-village.ac.id/index.php/istighna

Maskur Rosyid

Membincang Kembali Hubungan Syariah dan Filsafat

Mu'tazilī, ${ }^{240}$ dan sebaliknya jika lebih mendasarkan pada bunyi normative maka condong pada cara pandang Ash'arīin , dan sebagainya.

\section{Filsafat; Definisi dan Obyek Kajian}

Filsafat nerupakan padanan kata al-falsafah (bahasa Arab) dan philosophy (latin) yang berasal dari bahasa Yunani philosophia. Philosophia sendiri terdiri dari dua suku kata "philos" yang bermakna cinta (love) atau shabat dan "Sophia" yang berarti kebijaksanaan (wisdom), kearifan, dan pengetahuan. Dengan demikian secara terminology, filsafat berarti love of wisdom atau cinta kebijaksanaan, cinta kearifan. ${ }^{242}$ Istilah ini pertama kali digunakan oleh Pythagoras (abad VI SM) ketika diajukan pertanyaan kepadanya "apakah anda termasuk orang yang bijaksana" dia menjawab "saya hanya seorang philosophos, pecinta kebijaksanaan (lover of wisdom). Menurut pendapat lain, Pythagoras menjawab "saya hanya seorang yang mencintai pengetahuan". ${ }^{243}$ Jawaban tersebut merupakan reaksi atas kaum sophis yaitu sekelompok cendekiawan yang menggunakan hujah-hujahnya untuk mengalahkan lawan.

Ironisnya, kaum sophis tersebut menjual kepandaiannya untuk mencari untung dari lawan debatnya atau dari masyarakat dengan cara memberikan tarif

${ }^{240}$ Mu'tazilah atau disebut sebagai kaum rasionalis Islam berpendapat bahwa setiap tindakan Tuhan terdapat illahnya. Mereka beralasan seandainya tidak didasarkan atas motif tertentu maka perbuatan tersebut sia-sia sedangkan Tuhan MahaSuci dari perbuatan seperti itu. Motif tersebut banyak dijumpai dalam Alquran seperti Q.S al-Isra' (17): 12. Tuhan wajib menjaga dan memelihara kebaikan manusia. Alasan yang mereka ajukan bahwa Tuhan telah membebankan kewajiban beribadah kepada manusia sehingga Dia wajib memelihara kemaslahatan mereka dalam rangka menghilangkan kesulitan dalam melaksakan kewajiban tersebut. Jika tidak demikian maka berarti Tuhan telah membiarkan manusia dalam kesulitan dan Tuhan mustahil berbuat demikian.

${ }^{241}$ Ash'ariyah berpendapat lain, bahwa perbuatan Tuhan tidak didasarkan atas motif tertentu. Alasan yang mereka ajukan adalah seandainya suatu perbuatan didasarkan atas motif maka berarti ia memerlukan sesuatu di luar dirinya. Sehingga dengan membutuhkan sesuatu di luar dirinya berarti ia mempunyai sifat tidak sempurna dan memerlukan sesuatu yang lain untuk menyempurnakannya. Sedang Tuhan tidak mungkin tidak sempurna, karena Tuhan MahaSempurna. Bahwa menjaga kebaikan manusia merupakan karunia Tuhan, dan bukan kewajiban Tuhan. Alasannya adalah mereka mempersamakan tindakan Tuhan seperti tindakan seorang Raja yang tidak ada kewajiban apapun yang melekat pada dirinya. Raja hanya mempunyai kewajiban manakala terdapat kekuasaan di atas dirinya. Sedang Tuhan adalah MahaRaja yang mempunyai kekuasaan tertinggi di atas segala-galanya. Karenanya tidak ada sesuatu kewajiban apapun yang melekat pada diri-Nya dan terkait dengan kemalsahatan manusia hanya merupakan karunia Tuhan yang diberikan pada manusia.

${ }^{242}$ Ali Maksum, Pengantar Filsafat dari Masa Klasik hingga Postmodernisme (Jogjakarta: ar-Ruzz Media, 2009), 15-16.

${ }^{243}$ Koento Wibisono, Dasar-Dasar Filsafat (Jakarta: Universitas Terbuka, 1989), 13. 
ISTIGHNA, Vol. 2, No 1, Januari 2019 P-ISSN 1979-2824

Homepage: http://e-journal.stit-islamic-village.ac.id/index.php/istighna

Maskur Rosyid

Membincang Kembali Hubungan Syariah dan Filsafat

atau bayaran atas pendapat yang dimintakan kepadanya. ${ }^{244}$ Mengherankan ketika sophis justru kehilangan maknanya ditangan kaum sophis. Terlepas dari itu semua, kata philosophia telah menjadi kata atau istilah yang cukup populer pada masa Socrates dan Plato. ${ }^{245}$

Definisi filsafat lebih dari sekedar pemahaman atas terminologi filsafat, bahkan jumlah definisi filsafat adalah sebanyak jumlah para filsuf yang pernah ada dan yang saat ini ada, di dunia. Para filsuf Sokrates misalnya mengartikan filsafat sebagai ilmu yang digunakan untuk mengetahui dan memahami hakikat alam dan relaitas dengan mengandalkan akal budi. Berbeda dengan Plato yang mengatakan bahwa filsafat adalah ilmu pengetahuan yang berusaha meraih kebenaran yang asli dan murni, penyelidikan tentang sebab-sebab dan asas-asas yang paling kahir dari yang ada. Lebih dari itu, Aristo mendefinisikan filsafat sebagai ilmu pengetahuan yang senantiasa berupaya mencari prinsip-prinsip dan penyebab-penyebab dari realitas yang ada. Sedangkan Rene Descartes, adalah hipunan dari segala pengetahuan yang pangkal penyelidikannya mengenai Tuhan, alam, dan manusia. ${ }^{246}$

Definisi filsafat -sebagai telah disebutkan- masih terlampau banyak untuk disebutkan satu persatu, sebab masing-masing dilusf mempunyai akal yang berbeda dalam memahami filsafat. Sebut saja William James, Beerling, Louis O. Kattsoff, Harold H. Titus, Poedjawijanto, Sidi Gazalba, dan sebagainya. Hanya saja dapat ditarik sebuah kesimpulan sementara bahwa filsafat adalah kegiatan berpikir secara radikal-mendalam, mendasar- sistematis, dan universal tentang segala yang ada dan dimungkinkan ada. Organ penting dalam kegiatan berfilsafat adalah akal dan pengetahuan, sebab tanpa keduanya mustahil seseorang dalam menyelami dunia filsafat.

Obyek kajian filsafat terdiri dari dua bagian, pertama; material, yaitu segala sesuatu yang menjadi masalah, artinya bahwa segala sesuatu bisa jadi masalah jika dikaji menggunakan filsafat. Obyek material filsafat tersebut menurut

\footnotetext{
244 Murtadha Muthahhari, Tema-Tema Penting Filsafat Islam (Bandung: Yayasan Muthahhari, 1993), 11.

${ }^{245}$ Jan Hendrik Rapar, Pengatar Filsafat, 14.

${ }^{246}$ Ali Maksum, Pengantar Filsafat dari Masa Klasik hingga Postmodernisme, 16-21.
} 
ISTIGHNA, Vol. 2, No 1, Januari 2019 P-ISSN 1979-2824

Homepage: http://e-journal.stit-islamic-village.ac.id/index.php/istighna

Maskur Rosyid

Membincang Kembali Hubungan Syariah dan Filsafat

Saefuddin Ashari mencakup tiga persoalan, pertama; Hakikat Tuhan, kedua; Hakikat Alam, dan ketiga; Hakikat Manusia. Bagian kedua dari obyek filsafat adalah formal, yaitu usaha untuk mencari keterangan secara radikal tentang obyek material filsafat.

\section{Filsafat dalam Islam}

Ada yang megatakan bahwa Islam tidak pernah dan bisa memiliki filsafat yang independen. Adapun filsafat yang dikembangkan oleh para filsuf Muslim adalah pada dasarnya filsafat Yunani, bukan filsafat Islam. Ada lagi yang mengatakan bahwa nama yang tepat untuk itu adalah filsafat Muslim, karena yang terjadi adalah filsafat Yunani yang kemudian dipelajari dan dikembangkan oleh para filsuf Muslim. Ada lagi yang mengatakan bahwa nama yang lebih tepat adalah filsafat Arab, dengan alasan bahwa bahasa yang digunakan dalam karyakarya filosofis mereka adalah bahasa Arab, sekalipun para penulisnya banyak berasal dari Persia, dan nama-nama lainnya seperti filsafat dalam dunia Islam. ${ }^{247}$

Terlepas dari perbedaan tersebut, hal yang perlu diperhatikan adalah bahwa Islam mempunyai sejarah dalam pertentangan akal dan wahyu, yang dibingkai dalam persoalan ilmu kalam. Dalam kasus tersebut, muncul 2 mazhab besar yang kemudian mengilhami setiap pemikir pada tahap selanjutnya. Dua mazhab tersebut adalah Mu'tazilah sebagai ahl ra'y dan Ash'ariyah. Tradisi tersebut berkenaan dengan hal ihwal Tuhan, sehingga Tuhan -sebagaimana filsafat metafisika- menjadi bahan kajian yang menjadi perdebatan terus menerus.

Selain kajian akal dan wahyu yang bermuara pada kajian telogi (ilmu kalam), juga persoalan syariah. Pertarungan akal dan wahyu berpengaruh pada syariah, baik dimaknai terbatas sebagai hokum maupun ketika dimaknai secara luas sebagai agama. Dua doktrin tersebut -ilmu kalam dan syariah- sama-sama mempunyai pengaruh yang besar dalam Islam, sehingga tidak bisa dikatakan bahwa tradisi filsafat dalam Islam mengadopsi dari Yunani.

${ }^{247}$ Mulyadhi Kartanegara, "Masa Depan Filsafat Islam: Antara Cita dan Fakta" Makalah pada ulang tahun Paramadinan ke xx, Jakarta 2006. Lihat pula; Muhhammed 'Abid al-Jabiri, Kritik Pemikiran Arab Wacana Baru Filsafat Islam (Terj. Burhan) (Yogyakarta: Fajar Pustaka Baru, 2003). Dalam buku tersebut al-Jabiri menyebut filsafat dalam Islam sebagai Filsafat IslamArab. 
ISTIGHNA, Vol. 2, No 1, Januari 2019 P-ISSN 1979-2824

Homepage: http://e-journal.stit-islamic-village.ac.id/index.php/istighna

Maskur Rosyid

Membincang Kembali Hubungan Syariah dan Filsafat

Mazhab dalam teologi, sebagai telah disebutkan di atas, kemudian meluluskan beberapa mazhab, sebut saja Mu'tazilah, Ash'ariyah, Maturidiyah, Jabariyah, Qadariyah, dan sebagainya. Sementara dalam kajian syariah (fikih) muncul beberapa mazhab, seperti mazhab Ḥanafiyah, Mālikiyah, al-Shāfi‘iyah, dan Hanābilah. Jika dalam aliran kalam tersebut ahl ra'y dipegang oleh Mu'tazilah maka dalam syariah ahl ra'y disematkan pada pengikut Abū Hanīfah, jika ahl al-ḥadīth disematkan pada mazhab Mālikiyah maka kasus serupa dialamatkan pada Ash'ariyah, dan jika disebut sebagai aliran yang menengahi atas kedua kubu tersebut (Mu’tazilah-Ash'ariyah, Hanafiyah-Mālikiyah) maka dalam aliran kalam ada Matūridiyah sementara dalam syariah ada Shafí‘iyah. Dan seterunya, yang menggambarkan bagaimana Islam mempunyai tradisi berpikir dan berfilsafat yang ada.

Lantas, bagaimana kemudian banyak filsuf muslim yang berafiliasi atau bahkan berkiblat pada filsuf Yunani? Hal ini bisa dijawab sebagai berikut. Pada dasarnya, para pemikir (filsuf) muslim adalah pemikir yang kritis. Mulyadhi Kartanegara mengatakan bahwa mereka -filsuf muslim- tidak melulu membela filsafat Yunani, sebab sekalipun Ibn Sīnā yang sering dikelompokkan sebagai filsuf Peripatetik, namun ia tak segan-segan mengertik pandangan Aristoteles, kalau dirasa tidak cocok dan menggantikannnya dengan yang lebih baik. Beberapa tokoh lainnya seperti Suhrawardi, Umar b. Sahlan al-Ṣāwī, dan Ibn Taymiyyah, juga mengritik sistem logika Aristotetles. Sementara al-'Āmirī mengritik dengan pedas pandangan Empedokles tentang jiwa, karena dianggap tidak sesuai dengan pandangan Islam. ${ }^{248}$

Nasib filsafat (Islam dan Yunani) justru semakin kusut, lantaran kajian ini sering dimaknai hanya sebatas metafisik saja, sedangkan fisika dan matematika sering dilupakan. Padahal jika kita tengok beberapa karya filsuf muslim, dalam satu buku tentang filsafat maka akan ditemukan beberapa bab seperti tentang logika, matematika dan fisika. Tulisan buah karya filsuf muslim sedemikian lengkap pada setiap bidang tersebut, sehingga kita misalnya memiliki beberapa jilid tentang logika, meliputi pengantar, kategori, analitika priora, analitika

\footnotetext{
${ }^{248}$ Mulyadhi Kartanegara, "Masa Depan Filsafat Islam: Antara Cita dan Fakta”, 1.
} 
ISTIGHNA, Vol. 2, No 1, Januari 2019 P-ISSN 1979-2824

Homepage: http://e-journal.stit-islamic-village.ac.id/index.php/istighna

Maskur Rosyid

Membincang Kembali Hubungan Syariah dan Filsafat

posteriora, topika, dialektika, retorika, sopistika dan poetika. Sedangkan untuk matematika, ditemui beberapa jilid meliputi, aritmatika, geometri, astronomi dan musik. Untuk fisika, meliputi bidang kosmologi, seperti tentang langit, meteorologi, kejadian dan khancuran yang menandai semua benda fisik, tentang batu-batuan (minerologi), tumbuh-tumbuhan (botani), hewan (zoologi), anatomi, farmakologi, kedokteran dan psikologi. Dan tentang metafisika (al-'ilm al-ilahi) yang meliputi bidang ketuhanan, malaikat dan akal-akal, dan hubungan mereka dengan dunia fisik yang dibahas dalam bidang fisika. ${ }^{249}$

Berfilsafat, oleh Ibn Rushd dihukumi wajib, dengan alasan akal pikiran manusia yang diberikan Tuhan tidak lain digunakan untuk memikirkan tentang alam, manusia, dan berujung pada Tuhan. Bagaimana mungkin seorang mengetahui hakikat segala sesuatu tapi tidak berpikir? Demikian pula al-Kindi ${ }^{250}$, seorang filsuf pertama Islam, menyatakan bahwa berpikir rasional tanpa mengenyampingkan kelestarian ajaran Islam mutlak diperlukan. Dengan berfilsafat, setiap manusia pasti akan menemukan jalan kebenaran sehingga hokum yang kaku yang dibuat oleh orang yang tidak berpikir mengenai manusia dan alam seperti tersesar jauh dari kebenaran. Di sisi lain, banyak ilmuwan yang menentang filsafat, dengan alasan berpikir secara radikal tentang Tuhan berujung pada kekafiran.

Sungguhpun demikian, menurut Mulyadhi, saat ini umat Islam telah dilanda berbagai persoalah ilmiah filosofis, yang datang dari pandangan ilmiah-filosofis Barat yang bersifat sekuler. Berbagai teori ilmiah, dari berbagai bidang, fisika, biologi, psikologi, dan sosiologi, telah, atas nama metode ilmiah, menyerang fondasi-fondasi kepercayaan agama. Tuhan tidak dipandang perlu lagi dibawa-

249 Lihat misalnya karya Ibn Sīnā yang berjudul al-Shifā' demikian pula karya menumentalnya al-Qanūn fi al-Tibb yang kemudian menjadi rujukan ilmu kedokteran di Barat. Mulyadhi Kartanegara, "Masa Depan Filsafat Islam: Antara Cita dan Fakta", 2.

${ }^{250}$ Abū Yūsuf Ya'qūb Ibn Ishāa al-Kindī (185-269 H/796-873 M), bernenk moyang suku Kinda sebuah daerah besar di Arab Selatan. Beliau menyandang gelar Filsuf Arab, ayahnya seorang gubernur di Kufa dan al-Kindi lahir ketika ayahnya menduduki jabatan tersebut. Belajar di Basra yang kemudian hari menjadi pusat intelektual Islam, kemudian menetap di Baghdad. Logika, metafisika, aritmatika, kedokteran, telogi, dan sebagainya merupakan keahliannya yang menghantarkannya kepada kebaktian kepada ilmu pengetahuan. Ia memberikan sumbangan besar melalui integrasi Yunani dan Islam. 
ISTIGHNA, Vol. 2, No 1, Januari 2019 P-ISSN 1979-2824

Homepage: http://e-journal.stit-islamic-village.ac.id/index.php/istighna

Maskur Rosyid

Membincang Kembali Hubungan Syariah dan Filsafat

bawa dalam penjelasan ilmiah. ${ }^{251}$ Oleh karena itu, filsafat Islam menjadi penting untuk tetap dilestarikan guna menjawab problematika kemanusiaan, ilmu pengetahuan, dan tentang kealaman yang semakin jauh dari Tuhan.

\section{Diskursus Agama dan Filsafat}

Agama dan filsafat pada dasarnya bisa dikelompokkan pada pola hubungan mutualisme, yaitu saling memberikan dukungan. Filsafat yang pada pengetiannya adalah beripikir secara radikal, sistematis, dan universal tentu jika dipandang sebelah mata maka akan membahayakan agama Islam. hal tersebut bisa dibenarkan dengan catatan bahwa filsafat yang dipelajari adalah filsafat barat yang beragam yang tidak berlandaskan pada Islam.

Awalnya, kelompok yang memusuhi filsafat (elit Arab) oleh al-Kindi disebutkan sebagai reaksi ketakutan mereka karena takut kehilangan posisi yang tidak seharusnya ditempati, bahkan mereka menjual agama sehingga pada dasarnya mereka tidak beragama. Lebih lanjut, ia mengatakan bahwa antara agama dan filsafat bisa saling cocok dan harmonis, sebab keduanya menuju pada satu titik temu yaitu yang benar. Keduanya membincangkan kebenaran Tuhan, alam, dan manusia. Bahkan Alquran dan perkataan Nabi saw. (hadis) hanya bisa dimengerti melalui penalaran dan tidak akan diketahui oleh mereka yang menolak rasionalitas. ${ }^{252}$

${ }^{251}$ Mulyadhi Kartanegara, "Masa Depan Filsafat Islam: Antara Cita dan Fakta”, 2-4. Misalnya bagi Laplace (w. 1827), kehadiran Tuhan dalam pandangan ilmiah hanyalah menempati posisi hipotesa. Dan ia mengatakan, sekarang saintis tidak memerlukan lagi hipotetsa tersebut, karena alam telah bisa dijelaskan secara ilmiah tanpa harus merujuk kepada Tuhan. Baginya, bukan Tuhan yang telah bertanggung jawab atas keteraturan alam, tetapi adalah hukukm alam itu sendiri. Jadi Tuhan telah diberhentikan sebagai pemelihara dan pengatur alam. Atau dalam ranah biologi, Tuhan tidak lagi dipandang sebagai pencipta hewan hewan, karena menurut Darwin (w. 1881), munculnya spesies-spesies hewan adalah karena mekanisme alam sendiri, yang ia sebut sebagai seleksi alamiah (natural selection). Menurutnya hewan-hewan harus bertransmutasi sendiri agar ia dapat tetap survive, dan tidak ada kaitannya dengan Tuhan. bidang psikologi, Freud (w. 1941) telah memandang Tuhan sebagai ilusi. Baginya bukan Tuhan yang menciptakan manusia, tetapi manusialah yang menciptakan Tuhan. Tuhan, sebagai konsep, muncul dalam pikiran manusia ketika ia tidak sanggup lagi menghadapi tantangan eksternalnya, serti bencana alam dll., maupun tantangan internalnya, ketergantungan psikologis pada figur yang lebih dominan. Sedangkan Emil Durkheim, menyatakan bahwa apa yang kita sebut Tuhan, ternyata adalah Masyarakat itu sendiri yang telah dipersonifikasikan dari nilai-nilai sosial yang ada. Dengan demikian jelaslah bahwa, dalam pandangan sains modern Tuhan tidak memiliki tempat yang spesial, bahkan lama kelamaan dihapus dari wacana ilmiah.

${ }^{252}$ Muhhammed 'Abid al-Jabiri, Kritik Pemikiran Arab Wacana Baru Filsafat Islam, 8586. 
ISTIGHNA, Vol. 2, No 1, Januari 2019 P-ISSN 1979-2824

Homepage: http://e-journal.stit-islamic-village.ac.id/index.php/istighna

Maskur Rosyid

Membincang Kembali Hubungan Syariah dan Filsafat

Pertentangan agama dengan filsafat menurut al-Farabi ${ }^{253}$ terletak pada pengungkapannya. Jika agama lebih memilih menggunakan metode retoris dan dialektis maka filsafat menggunakan metode demonstrative. Hal tersebut bisa didamaikan dengan menganggap bahwa apa yang dikatakan agama sebagai alegori dari apa yang dikatakan filsafat. Al-Farabi bahkan bermimpi mendirikan sebuah kota yang penuh dengan kebaikan, sebuah kota rasio, harmoni, persaudaraan, dan keadilan. ${ }^{254}$

Terlepas dari itu, filsafat dapat melindungi agama dari serangan berbagai ancaman dan serangan ilmiah-filosofis. Tentang Tuhan misalnya, telah banyak para filsuf muslim yang menjawab dengan nalar filsufif, tidak sekedar dogmatis. Juga mengenai persoalan genostisime (sufisme, mistisisme) yang telah banyak dijawab dengan pendekatan filosofis.

\section{Kesimpulan}

Semakin berpikir seseorang maka semakin tinggi tingkat keberagamaannya. Kesimpulan ini terbaca dari uraian di atas. Ibn Rushd secara baik menjelaskan hubungan antara syariah dengan filsafat, sebagai telah didiskusikan di atas, sebagai hubungan mutualisme. Keduanya dapat dijadikan sebagai dasar pengetahuan. Mempertentangkan keduanya sama dengan mengakui ada yang lemah di antara keduanya, padahal baik secara 'aqlī maupun naqlī, keduanya sama-sama mendapatkan legitimasi yang sah. Melalui epistemologi khațabiyyah, jadaliyyah, dan burhāniyah baik melalui takwil maupun perangkat qiyās, Ibn Rushd membuktikan hubungan baik kedua term tersebut.

\section{Daftar Pustaka}

'Aqqād, 'Abbās Mạ̣mūd al-. Ibn Rushd. Mesir: Dār al-Ma'ārif, t.th.

'Irāqī, Muḥammad 'Ațịf Al-. Al-Naz'ah al- 'Aqliyah fi Falsafah Ibn Rushd. Kairo:

Dār al-Ma’ārif, 1979.

${ }^{253}$ Abū Nașr Muhammad ibn Muhammad ibn Turkhan al-Farabī (Abunaser) meninggal pada tahun 339 H/950 M. Berasal dari Farab, Transoxania (Iran paling Utara) tapi hidup di Damaskus. Beliau menkonsentrasikan diri untuk membaca filsafat di samping bekerja sebagai tukang kebun. Kemudian pergi ke Baghdad untuk belajar kepada dua ahli logika yaitu Mata Ibn Yunus dan Yuhana Ibn Haylan. Beliau terkenal sebagai guru kedua karena berhasil menjelaskan logika aristoteles sebagai (guru pertama).

${ }^{254}$ Muhhammed 'Abid al-Jabiri, Kritik Pemikiran Arab Wacana Baru Filsafat Islam, 87. 
ISTIGHNA, Vol. 2, No 1, Januari 2019 P-ISSN 1979-2824

Homepage: http://e-journal.stit-islamic-village.ac.id/index.php/istighna

Maskur Rosyid

Membincang Kembali Hubungan Syariah dan Filsafat

'Ubaydī, Ḥammadī al-. Ibn Rushd wa 'Ulūm al-Sharī'ah al-Islāmiyyah. Beirut:

Dār al-Fikr al-'Arabī, 1991.

Abduh, Muhammad. Ilmu dan Peradaban Islam Menurut Islam dan Kristen (terj.

Mahyuddin Syah). Bandung: Diponegoro, 1992.

Abdullah, M. Amin. “Al-ta'wil al-'ilmi: Ke Arah Perubahan Penafsiran Kitab Suci”, dalam Al-Jamiah, Vol. 39, Number. 2 July-Desember 2001.

Ahmad, Z. Abidin. Riwayat Hidup Ibnu Rushd (Averroes). Jakarta: Bulan Bintang, 1975.

Ahmad, Zainal Abidin. Riwayat Hidup Ibn Rushd. Jakarta: Bulan Bintang: 1975.

Ahwani, Ahmad Fuad al-. Filsafat Islam. Jakarta: Pustaka Firdaus,1997.

Asari, Hasan. "Dari Yunani Hingga Renaisans: Melacak Peranan Peradaban Islam

Dalam Tradisi Intelektual Barat” dalam Journal Analytica Islamica, Vol. I, No. I, 1999.

Ashmawī, Muḥammad Sa‘̄̄id al-. Nalar Kritis Syari'ah (Terj. Luthfi Tomafi). Yogyakarta: LKiS, 2012.

Bachtiar, Amsal. Filsafat Agama 1. Jakarta: Logos, 1997.

Baghdādī, 'Abd al-Raḥmān al-Jawzī al-. Talbīs al-Iblīs. Kairo: Idārah al-Ṭibā'ah al-Munīriyah, $1368 \mathrm{H}$.

Bertens, K. Sejarah Filsafat Yunani. Yogyakarta: Kanisius, 1975.

Chandra, Edy. "Relasi Agama dan Filsafat" artikel dalam http://www.academia.edu/1887409/Relasi_Agama_dan_Filsafat_Menurut_I bnu_Rushd diakses pada 23 September 2013, 00:46 WIB.

Coulson, Noel J. Conflicts and Tensions in Islamic Jurisprudence. Chicago \& London: the University of Chicago Press, 1969.

Ehwani, A.F. al- "Ibn Rushd" dalam M.M Syarif (ed.), A History of Muslim Philosophy, Vol. 1. Wisbaden: Otto Harrassowitz, 1963.

Fyzee, Asaf A.A. Outlines of Muhammadan Law. Oxford: Oxford University Press, 1964.

Ghan̄̄, 'Abdul Maqsūd 'Abdul. Al-Tawfiq Baynal-Dīn wa al-Falsafah 'Inda Falāsifah al-Islām fì al-Andalus (Agama dan Filsafat) terj. Saifullah \& Ahmad Faruq. Yogyakarta: Pustaka Pelajar, 2000. 
ISTIGHNA, Vol. 2, No 1, Januari 2019 P-ISSN 1979-2824

Homepage: http://e-journal.stit-islamic-village.ac.id/index.php/istighna

Maskur Rosyid

Membincang Kembali Hubungan Syariah dan Filsafat

Ghazālī, Abū Ḥamīd al-. al-Mustashfā min 'Ilm al-Uṣūl. Beirut: Dār al-Fikr, 1986. Tahāfut al-Falāsifah. Kairo: Dār al-Ma’ārif, 1928.

. Fayșāl al-Tafarruqah Bayn al-Islām wa Zindīqah. Beirut: al-Maktab al-Islāmī, $1390 \mathrm{H}$.

Hamlyn, D.W. "History of Epistemology", dalam Paul Edward (ed.) The Encyclopedia of Philosophy. New York: Mac Millan, 1972.

Hamzah Dan Wa Muna, “Epistemologi Ibnu Rusyd Dalam Merekonsiliasi Agama Dan Filsafat” Zawiyah Jurnal Pemikiran Islam, Vol. 4 No. 1, Juli 2018.

Hanafi, A. Pengantar Filsafat Islam. Jakarta: Bulan Bintang, 1976.

Hanafi, Ahmad. Theoligy Islam (Ilmu Kalam). Jakarta: Bulan Bintang, 1991.

Ḥasaballāh, 'Alī. Ușūl al-Tashrī’ al-Islāmī. Qahirah: Dār al-Fikr al-'Arabī, 1997.

Hasan, Fuad. Pengantar Filsafat Barat. Jakarta: Pustaka Jaya, 1996.

Ḥasan, Husayn Hamīd. Naẓariyah al-Maṣlahah. Kairo: Dār al-Naḥ̣ah al'Arābiyah, 1971. .Ușūl al-Fiqh. Mesir: t.p, 1970.

Iqbal, Muhammad. Ibn Rushd \& Averroisme. Jakarta: Gaya Media Pratama, 2004.

Ismail, Asep Usman. "Integrasi Syariah dengan Tasawuf” Ahkam Jurnal Ilmu Syariah, Vol. xii, No. 1, 2012.

Jābirī, Muhammed 'Abid al-. Problem Peradaban: Penelusuran Jejak Kebudayaan Arab Islam dan Timur (Terj. Sumarwoto Dema dan Mosiri). Yogyakarta: Belukar, 2004.

- Kritik Nalar Arab: Formasi Nalar Arab (Kritik Tradisi Menuju Pembebasan dan Pluralisme Wacana Interreligius) (Terj. Imam Khoiri). Yogyakarta: IRCiSod, 2003.

Kartanegara, Mulyadhi. "Masa Depan Filsafat Islam: Antara Cita dan Fakta" Makalah pada ulang tahun Paramadinan ke xx, Jakarta 2006.

Kattsof, L.O. Pengantar Filsafat (terj. Soejono Soemargono). Yogyakarta: Tiara Wacana, 1989.

Khaldūn, Ibn. "Shifā' al-Masā'il li Tahdhīb al-Masā'il”, dalam 'Abd al-Qādir Maḥmūd, al-Falsafah al-Ṣüfiyah fì al-Islām. Kairo: Dār al-Fikr al-'Arabī, 1966. 
ISTIGHNA, Vol. 2, No 1, Januari 2019 P-ISSN 1979-2824

Homepage: http://e-journal.stit-islamic-village.ac.id/index.php/istighna

Maskur Rosyid

Membincang Kembali Hubungan Syariah dan Filsafat

Khallāf, 'Abd al-Wahhāb. Maṣādir al-Tashrī' al-Islāmī fì mā lā Naṣs fì hā. Kairo:

Ma’had al-Dirāsāt al-'Arabiyyah al-‘Āliyah, 1955. . 'Ilm Ușūl al-Fiqh. Kairo: Dār al-Qalam, 1978.

Madjid, Nurcholis. Kaki Langit Peradaban Islam. Jakarta: Paramadina, 1997.

Maksum, Ali. Pengantar Filsafat dari Masa Klasik hingga Postmodernisme. Jogjakarta: ar-Ruzz Media, 2009.

Mas'ud, M. Khalid. Islamic Legal Philosophy. Islamabad: Islamic Research Institute, 1984.

Mas'udi, Masdar F. "Meletakkan Kembali Maṣlaḥah Sebagai Acuan Syari’ah” Jurnal 'Ulum al-Qur'an, Vol. VI, No. 3, 1995.

Mu'nis, Ḥusayn. 'Ālam al-Islām. Kairo: Dār al-Ma'ārif, 1973.

Mubarak, Jaih. "Pengantar" dalam Cecep Sumarna, Rekonstruksi Ilmu. Bandung: Benang Merah Press, 2005.

Munawwir, A.W. Kamus al-Munawwir Arab-Indonesia Terlengkap. Surabaya: Pustaka Progressif, 1997.

Mūsā, Muḥammad Yūsuf. Bayn al-Dīn wa al-Falsafah: fì Ra y Ibn Rushd wa Falāsifah al- 'Aṣr al-Wasīṭ. Kairo: Dār al-Ma'ārif, 1968.

Muthahhari, Murtadha. Tema-Tema Penting Filsafat Islam. Bandung: Yayasan Muthahhari, 1993.

Nadim, Ibn. the Fihris dalam Muhammed 'Abid al-Jābirī, Kritik Pemikiran Islam Wacana Baru Filsafat Islam (Terj. Burhan). Yogyakarta: Fajar Pustaka Baru, 2003.

Nadwī, Abū al-Hasan al-. Islam and the World. Lucknow: Academy of Islamic Research and Publication, 1979.

Nasution, Harun. Filsafat dan Mistisisme dalam Islam, Cet. Ke IX. Jakarta: Bulan Bintang, 1973. . Islam Rasional. Bandung: Mizan, 1995.

Nasution, Hasyimsyah. Filsafat Islam. Jakarta: Gaya Media Pratama, 2002.), 116.

Qāsim, Mạ̣mūd. Falsafah Ibn Rushd wa Atharruhā fì al-Tafkīr al-Gharbī. Sudan: Jami’ah Ummi Durman al-Islāmiyah, 1967.

Qaț̣ān, Manna' Khalīl. al-Tashrī’ wa al-Fiqh al-Islāmī. Beirut: Dār al-Fikr, 1982. 
ISTIGHNA, Vol. 2, No 1, Januari 2019 P-ISSN 1979-2824

Homepage: http://e-journal.stit-islamic-village.ac.id/index.php/istighna

Maskur Rosyid Membincang Kembali Hubungan Syariah dan Filsafat

Qudamah, Ibn. Rawḍah al-Nadhīr wa al-Ju'annah al-Munādhir. Beirut: Mu'asasah al-Risālah, 1978.

Rapar, Jan Hendrik. Pengantar Filsafat. Yogyakarta: Kanisius, 1996

Rāzī, Fakhr al-Dīn al-. al-Maḥṣūl fì 'Ilm al-Uṣūl al-Fiqh. Riyadh: Dār al-Fikr, 1981.

Rosyid, Maskur, Implementasi Konsep Maslahat al-Tufi. Magelang: PKBM "Ngudi Ilmu", 2013.

Rushd, Abū al-Walid Muḥammad ibn Aḥmad Ibn. Bidāyah al-Mujtahid wa Nihāyah al-Muqtașid. T.tp: Dār al-Fikr, t.th.

. Kitāb Faṣl al-Maqāl wa Taqrīr ma Bayna al-Hikmah wa al-Sharī'ah min al-Ittișāl. Kairo: Dar al-Ma'arif, t.t.

. Tahāfut al-Tahāfut, al-Qism al-Awwal, Taḥqīq: Sulaymān Dunya, Cet. I. Mesir: Dār al-Ma’ārif, 1964.

Salam, M. Yuseran. Hadits-Hadits Thaharah dalam Kitan Bidayah al-Mujtahid. Yogyakarta: UII Press, 2003.

Schact, Joseph. An ntroduction to Islamic Law. Oxford: Oxford University, 1964.

Shāṭibī, Abū Ishāạ Ibrāhīm ibn Mūsā al-Lakhmi Al-. Al-Muwāfaqāt fì Uṣūl alAḥkām, I. Kairo: Dār al-Fikr, 1341 H.

Shiddiqi, Nuruzzaman. Tamaddum Muslim Bunga Rampai Kebudataan Muslim. Jakarta: Bulan Bintang, 1986.

Shihab, M. Quraish. Membumikan al-Quran: Fungsi dan Peran Wahyu dalam Masyarakat. Bandung: Mizan, 1994.

Sholeh, A. Khudori, (ed.), "Model Epistemologi Islam al-Jābirî” dalam Pemikiran Islam Kontemporer. Yogyakarta: Jendela, 2003.

Sholikhin, Muhammad. Filsafat dan Metafisika dalam Islam; sebuah Penjelajahan Nalar, Pengalaman Mistik, dan Perjalanan Aliran Manunggaling Kawula Gusti. Yogyakarta: Narasi, 2008.

Siradj, Said Aqiel. Islam Kebangsaan Fiqh Demokratik Kaum Santri. Jakarta: Pustaka Ciganjur, 1999.

Sirri, Mun'im A. Sejarah Fiqih Islam Sebuah Pengantar. Surabaya: Risalah Gusti, 1996. 
ISTIGHNA, Vol. 2, No 1, Januari 2019 P-ISSN 1979-2824

Homepage: http://e-journal.stit-islamic-village.ac.id/index.php/istighna

Maskur Rosyid

Membincang Kembali Hubungan Syariah dan Filsafat

Sulayman, Umar. Tārikh al-Fiqh al-Islām. Kuwait: Maktabah al-Falah, 1982.

Taymiyah, Ibn. Iqtị̣ā' al-Șirāṭ al-Mustaqìm. Beirut: Dār al-Fikr, t.th.

Wibisono, Koento. Dasar-Dasar Filsafat. Jakarta: Universitas Terbuka, 1989.

Yusuf, Muhammad. "Negara Ideal Menurut Ibn Rushd”, Jurnal Ilmu-Ilmu Ushuluddin Essensia, Vol. 4, No. 2, 2003.

Zahra, Muḥammad Abū. Ușūl al-Fiqh. Mesir: Dār al-Fikr al-'Arabī, t.th.

Zaid, Nasr Hamid Abu. Tekstualitas al-Quran: Kritik terhadap Ulumul Qur'an. Yogyakarta: LKiS, 2003.

Zayd, Muṣțafā. al-Maṣlaḥah fi al-Tashrī’ al-Islāmī wa Najm al-Dīn al-Ṭüfì. ttp: Dār al-Fikr al-‘Arābī, 1954. 